\title{
Emotions in Motion: Myofascial Interoception
}

\author{
Bruno Bordoni ${ }^{\mathrm{a}-\mathrm{c}}$ Fabiola Marellib,c \\ a Department of Cardiology, Santa Maria Nascente Institute IRCCS - Hospitalization and Care with Scientific Address, \\ Don Carlo Gnocchi Foundation, Milan, Italy; \\ ${ }^{\mathrm{b}}$ CRESO School, Osteopathic Centre for Research and Studies, Falconara Marittima, Italy; \\ ${ }^{c}$ CRESO School, Osteopathic Centre for Research and Studies, Gorla, Italy
}

\section{Keywords}

Fascia - Myofascial · Osteopathic · Manual therapy . Interoception

\section{Summary}

There are numerous articles in the literature dealing with the myofascial system, on the physiological, pathological, macroscopic and microscopic level; yet, we still do not have a thorough knowledge of its functions, just as there is still no shared vision of how to classify it. Many professional manual practitioners are involved in its treatment and there are many emerging therapeutic approaches. What is still missing is the awareness that the body is also emotion. The myofascial continuum is able to stimulate the areas of the brain that deal with the emotional state, and manual treatment activates the interoceptive system. To optimize myofascial treatment, a psychologist should work alongside the manual practitioner, creating a multidisciplinary team that takes into account both the physical and emotional aspects.

(c) 2017 The Author(s). Published by S. Karger GmbH, Freiburg

\section{Introduction}

The fascia is one entity but, at the same time, it is very diverse; in fact, as will be described in this article, there is a fascial continuity and, despite having many different names, it has one embryological origin. At present, there is no single, uniform definition of the fascia, probably due to the scientific mark made by each professional figure in attempting to create a unique point of view [1-7].

\section{Schlüsselwörter}

Faszie - Myofaszial - Osteopatisch - Manuelle Therapie . Interozeption

\section{Zusammenfassung}

Es gibt eine Vielzahl von Artikeln in der Literatur, die sich mit dem myofaszialen System beschäftigen, auf der physiologischen, pathologischen, makroskopischen und mikroskopischen Ebene. Dennoch verfügen wir noch nicht über ein umfassendes Wissen zu seiner Funktion, genauso wie es noch keine übereinstimmende Meinung dazu gibt, wie das System zu klassifizieren ist. Viele professionelle Chiropraktiker beschäftigen sich mit seiner Behandlung, und viele therapeutische Ansätze werden derzeit entwickelt. Es fehlt jedoch das Bewusstsein dafür, dass der Körper auch Emotion ist. Das myofasziale Kontinuum kann die Areale des Gehirns stimulieren, die mit dem Gefühlszustand befasst sind, und eine manuelle Behandlung aktiviert das interozeptive System. Zur Optimierung einer myofaszialen Behandlung sollte der Chiropraktiker mit einem Psychologen zusammenarbeiten, sodass ein multidisziplinäres Team entsteht, das sowohl die physikalischen als auch die emotionalen Aspekte berücksichtigt.

Every body structure is wrapped in connective tissue, the fascia, creating a structural continuity that gives form and function to every tissue and organ. The fascial tissue is equally distributed throughout the entire body, enveloping, interacting with and permeating blood vessels, nerves, viscera, meninges, bones, and muscles, creating various layers at different depths and forming a tridimensional metabolic and mechanical matrix. The fascia constitutes an organ that can affect an individual's health $[8,9]$.

\section{KARGER}

Fax +497614520714 Information@Karger.com www.karger.com

$\begin{array}{ll}\text { C } 2017 \text { The Author(s) } & \text { Karger } \\ \text { Published by S. Karger GmbH, Freiburg } & \text { Open ciccess }\end{array}$

This article is licensed under the Creative Commons AttributionNonCommercial-NoDerivatives 4.0 International License (CC BY-NCND 4.0) (http://www.karger.com/Services/OpenAccessLicense). Usage difed moteil requreswiten peses asion.
Bruno Bordoni

Department of Cardiology

Santa Maria Nascente Institute IRCCS - Hospitalization and Care with Scientific Address, Don Carlo Gnocchi Foundation

Via Capecelatro 66, Milan 20142, Italy

bordonibruno@hotmail.com 
Each tissue is connected to another from the extracellular matrix (ECM) scaffolds; cells adhere to these ECM scaffolds (composed of collagens, glycoproteins, and proteoglycans) via binding of specific cell surface receptors known as integrins. The integrins at the cell surface form bridges between the inside and the outside of the cell, allowing a continuity of the fascial information with the cytoskeleton of the cell [10].

From an embryological perspective, the fascial system originates in the mesoderm, although according to some authors this connective network can be partially found in the neural crest (ectoderm), with particular reference to the cranial and cervical areas [11].

We can distinguish four fascial planes: the superficial fascia, the axial/appendicular fascia, the meningeal fascia, and the visceral fascia. The superficial or pannicular fascia is absent from the orifices, such as the eye sockets, nasal and oral passages, and aboral apertures; it is composed of irregularly organized connective tissue, with regional body differences regarding density and the presence of fat [12]. The most superficial part contains more fat than the innermost one, which has a more membranous nature [12]. The axial fascia or investing or deep fascia is peripherally fused with the previous layer and extends in depth through the body, surrounding the contractile areas, the vessels and nerves; there are the epimysium, the periosteum, the tissue that covers the tendons and ligaments, and the joint capsules [12]. The axial layer is formed by packets of irregularly organized collagen fibers and runs along the front and back of the spine, like two parallel rails [12]. Each muscle related to the spinal column and the upper and lower limbs is covered by the pannicular fascia, whilst below there is the axial fascia; there is, however, an interpenetration of the various fascial and muscular layers, so as to create a continuum [12]. The meningeal fascia surrounds the central nervous system, ending with the epineurium, which covers the peripheral nerve $[12,13]$. The visceral fascia extends from the cranial base to the pelvic cavity, covering all the organs and guiding the neurovascular and lymphatic packets towards the organs; the density of this fascia varies depending on its location in the body [12].

Fibroblasts are the foundation of the fascial system [9]. The fibroblasts adapt according to the metabolic- and mechanical-type stimuli present; they help distant areas to communicate with each other, thereby making the information available in real time to the whole body [9]. Thanks to the fibroblasts, the fascial layers communicate not only from a mechanical and metabolic point of view but also by means of a microvascular system, the Bonghan duct system, which is in turn composed of the same structures as the superficial fascia; it is a microscopic web, involving vessels and nerves, in varying directions, and is highly deformable [9]. Telocytes represent another cellular structure recently discovered in the fascial tissue, in particular in the fascia lata of the lower limb. They can be found alongside the fibroblasts and, like the latter, are able to communicate with distant cell bodies through their prolongations or telopodes, probably in order to allow better propagation of the metabolic information [14].

The connective tissue that constitutes the fascial system is anisotropic, which is a condition where there is no single characteris- tic or identical properties in all directions; this allows maximum adaptation in dealing with the exogenous and endogenous demands of the body [12]. The fascial anisotropy reflects the concept of 'biotensegrity', based on the presence of discontinuous compression elements (bones) that balance the stress generated or received by continuous tension elements (muscle and fascia) [8, 15]. The biotensegrity and anisotropy allow the fascial system to continuously and constantly adapt, always making it change instant by instant [12]. Any reduction of this fascial ability will lead to a pathological condition $[11,16,17]$.

\section{Myofascial Interoception}

Some pioneers of psychotherapy had the intuition to connect emotions to the body system. Wilhelm Reich, a student of Freud, considered the psyche as a mind-body functional unit; in his view, the body attitude reflects the psychological attitude [18]. The psychotherapist Alexander Lowen, a student and patient of Reich, continued the reflections of his teacher, deepening the concept of the body-mind relationship; according to his concepts, a long-term negative emotion can affect the body's response, altering the patient's posture [19]. They did not have full knowledge of the fascial system, but their ideas opened the way to the understanding of the body as also being emotion.

The myofascial system possesses a very fine and extensive, diversified and ever present innervation [12]. Proprioceptive myelinated terminations (Ruffini-, Golgi- and Pacini-type endings) can be found, in particular inside or in close proximity to the connective tissue in close relationship with the muscles. There are a multitude of free, unmyelinated, very fine terminations, especially in contact with the periosteum, layers like the endomysium and the perimysium, in the connective tissues of all the viscera [12]. Considering the total number of all these fascial receptors, some authors compare the sensitivity of the fascial system to that of the retina, as equal to or greater than it, making the fascial continuum the richest sensory organ [12]. These receptors are assigned to the functions of proprioception, nociception, and interoception [12].

Interoception is the awareness of the bodily condition based on the information derived directly from the body [20]. The pathways pertaining to interoception project towards the autonomic and medullar homoeostatic centers and the brainstem, where they are routed to the frontal cingulate cortex and the dorsal posterior insula, by the thalamocortical circuit [21]. Interoception can modulate the exteroceptive representation of the body, as well as pain tolerance; dysregulation of the pathways that manage or stimulate interoception could cause a distortion of one's own body image, influencing emotionality [21,22].

The receptors that send information about interoception are not only located in the viscera but also in the myofascial areas of the trunk and limbs [12]. In the myofascial continuum, the myelinated terminations constitute a small percentage (proprioceptors) compared to the unmyelinated ones, which represent approximately $80 \%$ of the total efferents [12]. Some authors like Schleip et 
al. [12] define these receptors as the interstitial receptors of the muscle, as they are found in the endomysium and perimysium; they are connected to both myelinated (type III or alpha-delta fiber) and unmyelinated (type IV or C fiber) afferent neurons. The activation of the $\mathrm{C}$ fibers is able to activate the areas of the brain that are usually involved in emotional states, such as the insular cortex, without activating the somatosensory cortex areas [23].

Manual practitioners, such as osteopaths, physiotherapists and manual therapists, act - with different approaches - on the myofascial system, and the techniques performed on the muscle districts are able, through the interoceptors, to stimulate the insular areas and emotionality. The different specialists adopt different techniques to approach the myofascial system. The physical therapist applies stretching, muscular reinforcement, and massages; osteopaths apply direct or indirect techniques on the fascia (e.g., techniques of pressure on the sore tissue and relaxation, or techniques of unwinding fascial tissue, respectively). The manual therapists and chiropractors can apply techniques to release the joints and, consequently, the neighboring fascial tissue [12].

These receptors are able to warn the insula of the tensional load to which the skeletal muscle is subjected, simply by the deformation of the structures that make up the fascia, with a sympathetic efferent response by increasing the local bloodstream and increasing the hydration of the ECM [24]. Myofascial techniques are able to act on psychological and emotional parameters $[25,26]$. A disorder involving the myofascial system will also have repercussions on the emotional state $[27,28]$. There is a strong relationship between the myofascial structure and the emotions.

We can say that the presence of a disorder of the myofascial continuum, during everyday movements and activities, can alter the emotional state of the person, as studies reveal in the presence of fibromyalgia and in other pathological situations [29-33]. It is possible to suppose that an emotional allodynia could be established originating from constant myofascial non-physiological afferents, which would bring the emotional state and the myofascial pathology to the same level. In fact, the very position of the body stimulates the areas of emotionality, and the presence of myofascial alterations leads to postural alterations [34-37]. A dysfunctional myofascial system alters the posture and the emotional state.

A manual approach to the myofascial system should be multidisciplinary, involving not only manual practitioners but also other health professionals such as psychologists. Many diseases comprise emotional disorders, but there is often little interest in the patient's emotional status [38]. Currently, not many data are available on the integration of the psychological approach with the manual therapy.

We hope that this text will stimulate practitioners who deal with the fascial continuum to involve further, different professionals, in order to be able to offer the patient a multidisciplinary team to optimize the treatment.

\section{Conclusions}

Every body structure is wrapped in connective tissue or fascia, creating a structural continuity that gives form and function to every tissue and organ. The fascial tissue is uniformly distributed throughout the body, enveloping, interacting with and permeating blood vessels, nerves, viscera, meninges, bones and muscles, creating various layers at different depths and forming a tridimensional metabolic and mechanical matrix. The fascial system is subject to manual treatment by various professionals, with the aim of restoring its function. The myofascial continuum is rich in interoceptors that are able to stimulate the areas of the brain that control the emotional state; manual therapy involves both the structure and the emotional sphere. A multidisciplinary approach is advisable for the patient; it should reflect the needs of the structure and, at the same time, the needs of the emotional state. The myofascial system is biunivocally linked to the emotions.

\section{Disclosure Statement}

The authors report no conflicts of interest in this work.

\section{References}

1 Schleip R, Klingler W: Schleip \& Klingler's response to Stecco's fascial nomenclature editorial. J Bodyw Mov Ther 2014;18:447-449.

2 Tozzi P: Tozzi's response to Stecco's fascial nomenclature editorial. J Bodyw Mov Ther 2014;18:450-451.

3 Myers T: Myers' response to Stecco's fascial nomenclature editorial. J Bodyw Mov Ther 2014;18:445-446.

4 Langevin H: Langevin's response to Stecco's fascial nomenclature editorial. J Bodyw Mov Ther 2014;18:444

5 Natale G, Condino S, Soldani P, Fornai F, Mattioli Belmonte M, Gesi M: Natale et al.'s response to Stecco's fascial nomenclature editorial. J Bodyw Mov Ther 2014;18:588-590

6 Kumka M: Kumka's response to Stecco's fascial nomenclature editorial. J Bodyw Mov Ther 2014;18:591-598.

7 Stecco C: Why are there so many discussions about the nomenclature of fasciae? J Bodyw Mov Ther 2014;18: 441-442.
8 Bordoni B, Marelli F: The fascial system and exercise intolerance in patients with chronic heart failure: hypothesis of osteopathic treatment. J Multidiscip Healthc 2015;8:489-494.

9 Bordoni B, Zanier E: Understanding fibroblasts in order to comprehend the osteopathic treatment of the fascia. Evid Based Complement Alternat Med 2015; 2015:860934.

10 Ingber DE: Tensegrity and mechanotransduction. J Bodyw Mov Ther 2008;12:198-200.

11 Bordoni B, Zanier E: Clinical and symptomatological reflections: the fascial system. J Multidiscip Healthc 2014;7:401-411.

12 Schleip R, Findley TW, Chaitow L, Huijing PA: Fascia: The Tensional Network of the Human Body. London, Churchill Livingstone/Elsevier, 2012.

13 Bordoni B, Bordoni G: Reflections on osteopathic fascia treatment in the peripheral nervous system. J Pain Res 2015;8:735-740.
14 Dawidowicz J, Szotek S, Matysiak N, Mielańczyk Ł, Maksymowicz K: Electron microscopy of human fascia lata: focus on telocytes. J Cell Mol Med 2015;19:25002506.

15 Turvey MT, Fonseca ST: The medium of haptic perception: a tensegrity hypothesis. J Mot Behav 2014;46 143-187.

16 Tozzi P: A unifying neuro-fasciagenic model of somatic dysfunction - underlying mechanisms and treatment part I. J Bodyw Mov Ther 2015;19:310-326.

17 Stecco A, Stern R, Fantoni I, De Caro R, Stecco C: Fascial disorders: implications for treatment. PM R 2016;8 161-168.

18 Shapiro D: Theoretical reflections on Wilhelm Reich's character analysis. Am J Psychother 2002;56:338-346.

19 Lowen A: [Bioenergetics. An interview with Dr. Alexander Lowen of New York. Interview by M. Carafa]. Minerva Psichiatr 1979;20:viii-xi. 
20 Domschke K, Stevens S, Pfleiderer B, Gerlach AL: Interoceptive sensitivity in anxiety and anxiety disorders: an overview and integration of neurobiological findings. Clin Psychol Rev 2010;30:1-11.

21 Tsay A, Allen TJ, Proske U, Giummarra MJ: Sensing the body in chronic pain: a review of psychophysical studies implicating altered body representation. Neurosci Biobehav Rev 2015;52:221-232.

22 Garfinkel SN, Critchley HD: Interoception, emotion and brain: new insights link internal physiology to social behaviour. Commentary on: 'Anterior insular cortex mediates bodily sensibility and social anxiety' by Terasawa et al. (2012). Soc Cogn Affect Neurosci 2013; 8:231-234.

23 Olausson HW, Cole J, Vallbo A, McGlone F, Elam M Krämer $\mathrm{HH}$, Rylander K, Wessberg J, Bushnell MC Unmyelinated tactile afferents have opposite effects on insular and somatosensory cortical processing. Neurosci Lett 2008;436:128-132.

24 Schleip R: Fascial plasticity - a new neurobiological explanation: part 1. J Bodyw Mov Ther 2003;7:11-19.

25 Fernández-Pérez AM, Peralta-Ramírez MI, Pilat A, Villaverde C: Effects of myofascial induction techniques on physiologic and psychologic parameters: a randomized controlled trial. J Altern Complement Med $2008 ; 14: 807-811$
26 Ferrell-Torry AT, Glick OJ: The use of therapeutic massage as a nursing intervention to modify anxiety and the perception of cancer pain. Cancer Nurs 1993; 16:93-101.

27 Rozisky JR, Fregni F, Caumo W: Association of anxiety with intracortical inhibition and descending pain modulation in chronic myofascial pain syndrome. BMC Neurosci 2014;15:42.

28 Volz MS, Medeiros LF, Tarragô Mda G, Vidor LP, Dall'Agnol L, Deitos A, Brietzke A, Rozisky JR, Rispolli B, Torres IL, Fregni F, Caumo W: The relationship between cortical excitability and pain catastrophizing in myofascial pain. J Pain 2013;14:1140-1147.

29 Ge HY, Wang Y, Fernández-de-las-Peñas C, GravenNielsen T, Danneskiold-Samsøe B, Arendt-Nielsen L: Reproduction of overall spontaneous pain pattern by manual stimulation of active myofascial trigger points in fibromyalgia patients. Arthritis Res Ther 2011;13:R48.

30 Alonso-Blanco C, Fernández-de-las-Peñas C, MoralesCabezas M, Zarco-Moreno P, Ge HY, Florez-García M: Multiple active myofascial trigger points reproduce the overall spontaneous pain pattern in women with fibromyalgia and are related to widespread mechanical hypersensitivity. Clin J Pain 2011;27:405-413.

31 Schmitter M, Keller L, Giannakopoulos N, Rammelsberg P: Chronic stress in myofascial pain patients. Clin Oral Investig 2010;14:593-597.
32 Younger JW, Shen YF, Goddard G, Mackey SC: Chronic myofascial temporomandibular pain is associated with neural abnormalities in the trigeminal and limbic systems. Pain 2010;149:222-228.

33 Torres Lacomba M, Mayoral del Moral O, Coperias Zazo JL, Gerwin RD, Goñí AZ: Incidence of myofascial pain syndrome in breast cancer surgery: a prospective study. Clin J Pain 2010;26:320-325.

34 Taylor KS, Seminowicz DA, Davis KD: Two systems of resting state connectivity between the insula and cingulate cortex. Hum Brain Mapp 2009;30:2731-2745.

35 Otadi K, Hadian MR, Talebian S, Shadmehr A, Emamdoost S, Shahriar G: The effect of myofascial neck pain on postural control: visual deprivation. J Back Musculoskelet Rehabil 2013;26:375-380.

36 Jones KD, King LA, Mist SD, Bennett RM, Horak FB Postural control deficits in people with fibromyalgia: a pilot study. Arthritis Res Ther 2011;13:R127.

37 Edwards J: The importance of postural habits in perpetuating myofascial trigger point pain. Acupunct Med 2005;23:77-82.

38 Bordoni B, Marelli F, Morabito B, Sacconi B: Manual evaluation of the diaphragm muscle. Int J Chron Obstruct Pulmon Dis 2016;11:1949-1956. 